\title{
Geographical Equity Effects Of The Homeowner Tax Subsidy
}

Tim Krumwiede, (Email: Krumwield@bryant.edu), Bryant University Raymond A. Zimmermann, (Email: RZimmerman@utep.edu), University of Texas at E1 Paso Pat Eason, (Email: PEason@utep.edu), University of Texas at El Paso

\begin{abstract}
The purpose of this study is to provide exploratory evidence concerning the degree to which geographical cost of living differentials interact with homeownership tax incentives in affecting tax system equity. Incorporating both federal and state homeowner tax subsidies calculated using the 1991 Ernst \& Young Tax Model File; the authors provide evidence concerning both horizontal and vertical equity in the system. Descriptive statistics and regression results provide findings which indicate positive and direct relationships between the homeowner tax subsidy and 1) taxpayer disposable income (increased regressivity in the tax system) and 2) taxpayer state of residence median housing values (decreased horizontal inequities between similarly situated homeowners in different states). These findings indicate that elimination of the homeowner tax subsidy accompanied by a direct subsidy would increase equity within the system. Furthermore, the findings suggest that the President's Advisory Panel on Federal Tax Reform (2005) recommendation for a home credit, with a limit based on average cost of housing within a taxpayer's area, will result in a more equitable distribution of the homeowner tax subsidy.
\end{abstract}

\section{GEOGRAPHICAL EQUITY EFFECTS OF THE HOMEOWNER TAX SUBSIDY}

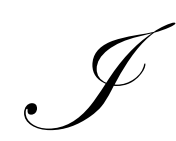

$\mathrm{t}$ is well known that federal income tax preferences such as the deductibility of home mortgage interest and real property taxes, the exclusion for imputed rent, and special provisions for the exclusion of gains from the sale of a personal residence effectively lower the cost of owner-occupied housing. Indeed, prior research suggests that this favorable tax treatment has actually increased homeownership in the United States (Rosen, 1979; Rosen and Rosen, 1980; Hendershott and Shilling, 1982). The desirability of this policy objective is often discussed in terms of the generation of positive externalities such as homeowners taking pride in and care of property by making improvements which in turn enhance associated neighborhoods. Homeownership may also increase an individual's feeling of social responsibility by providing a perceived stake in the nation (Rosen, 1988).

Examinations of the suitability of tax incentives used to reach this objective involve not only the effect of these externalities, but also potential tax subsidy effects on the distribution of tax burdens. These effects are often analyzed in the context of the concepts of horizontal equity and vertical equity. For this purpose, horizontal equity is characterized by similarly situated taxpayers paying similar amounts of tax. Vertical equity, on the other hand, is characterized by taxpayers in different situations paying relatively different amounts of tax.

For individuals believing that vertical equity is characterized by a progressive tax system, Follain and Ling (1991) present results suggesting that existing homeownership tax subsidies actually decrease vertical equity by increasing regressivity in the system and providing more tax savings to upper income individuals. Further, cost of living differences between states potentially exaggerate horizontal inequities already in the system by providing increased benefits to individuals in high cost of living areas relative to those living in low cost areas.

Using the Ernst \& Young/ University of Michigan Individual Model File of federal income tax returns (EY Model File), this study addresses horizontal and vertical equity effects characterizing the distribution of homeowner tax subsidies provided in the form of home mortgage interest and real property tax deductions. Horizontal equity 
issues are examined in the context of potential differences in the tax savings produced by these incentives between states. Vertical equity effects are considered in an analysis of the distribution of these subsidies among disposable income groups.

Consistent with Follain and Ling's (1991) findings, subsidies enjoyed by sample recipients in this study are generally larger for high income group recipients than low income group recipients. Also, the within group percentage of taxpayers receiving a subsidy increases as disposable income increases. While intuitively expected, these effects are even more pronounced when examined in comparisons which include both federal and combined (state and federal) subsidies across states.

The findings of this study support the conclusions of the President's Advisory Panel on Federal Tax Reform (2005) that the tax benefits for home mortgage interest should be shared more equally. To reach this objective, the Panel recommends that the deduction for mortgage interest be replaced with a Home Credit available to all homeowners, not just a select group of homeowners who itemize deductions. It is also recommended that the deduction for interest on mortgages on second homes and interest on home-equity loans be eliminated. Furthermore, the Panel suggests that a limit be placed on the amount of the Home Credit. These proposals are consistent with an effort to increase the vertical equity of the homeowner tax subsidy. Furthermore, it is recommended that the credit be adjusted for geographical variations in housing markets. This latter adjustment would increase the horizontal equity of the homeowners' subsidy.

The following paragraphs first provide a discussion of the concepts of horizontal and vertical equities in the context of homeowner tax incentives provided under the current federal individual income tax system. Next, descriptions of the data, analytical model and procedures used to examine homeowner subsidy equity effects are provided. Result analysis follows. Finally, conclusions and policy implications are presented.

\section{HORIZONTAL AND VERTICAL EQUITY}

Mill (1848) first suggested that individuals with equal incomes should pay equal taxes (horizontal equity), and those with higher incomes should pay relatively more in taxes (vertical equity). While these concepts have been generally accepted (Musgrave, 1990), differing conclusions concerning the degree of equity present in a particular provision or system can be dependent on the definition of equal considered. Taxpayers with equal incomes may not actually enjoy equal positions in terms of living standard potentials. This study details an analysis into the effect of a general disregard for the effect of cost of living differentials across geographical locations in determinations of an individual's equitable share of the federal income tax burden.

Assume that taxpayers A and B are both single with identical occupations. Taxpayer A lives in a major metropolitan area where the costs of housing, food and other essential elements of living are substantially higher than the costs of living in the rural area in which B lives. A and B receive before-tax salaries of $\$ 70,000$ and $\$ 50,000$, respectively. However, this $\$ 20,000$ salary difference exists only to equate cost of living differences between the two areas and allow both A and B to enjoy equal levels of current consumption. That is, A's $\$ 70,000$ can be used to purchase a basket of consumption goods similar to that purchasable with B's $\$ 50,000$ in the rural area.

For purposes of horizontal equity considerations, A and B are arguably in equal positions and should incur similar tax costs and benefit from similar tax subsidies. However, a progressive rate structure that does not incorporate cost of living differences produces higher marginal and average tax rates for A than B. As a result, horizontal equity within the system is potentially compromised.

This possible violation may be especially severe when examining the distribution of homeowner tax incentives. Large portions of cost of living differences occur because housing costs differ significantly from region to region. A review of the American Cost of Living Survey (Gale Research, Inc., 2002), illustrates this point. Composite cost of living indices for Amarillo, Texas and New York City, New York are reported at 92.7 and 239.2, respectively. Comparable housing cost indices are reported at 92.2 and 485.2, respectively. As indicated, the effect of housing cost differentials clearly dominates the divergence between composite cost of living indices. As a result, homeowner tax 
incentive provisions generally produce relatively larger deductions for home mortgage interest and real property taxes for taxpayers living in the more expensive location (New York City).

While real property tax differentials envelop ad valorem taxes which are correlated with high cost of living differences, prior literature provides no evidence of a strong relationship between differential home mortgage interest rates and costs of living. As a result, mortgage interest deduction differences generally result not from rate differentials between regions, but from regional variations in the interaction between housing values and the proportion of purchase price financed.

In this context, subsidy inequities (horizontal) occur for several reasons. First, mortgage interest and real property tax deductions constitute itemized deductions in an individual's federal taxable income calculation. Estimated as the benefit received solely due to these homeowner tax incentive provisions, the homeowner tax subsidy received is limited by a ceiling which equates to the excess of an individual's total itemized deductions over any allowable standard deduction. Taxpayers in high cost of living areas may be more likely to qualify as itemizers and receive benefit from the incentives. Second, taxpayers in high cost of living areas are more likely to report larger excess itemized deductions. Together, these arguments suggest that cost of housing differences across states cause taxpayers in equal consumption potential positions to benefit from different subsidies and pay different amounts of tax.

While no prior research has addressed subsidy horizontal equity effects resulting from cost of living differences, two primary studies have focused on federal income tax equity effects in relation to real estate. White and White (1965) examined horizontal inequities resulting from differences in the federal income tax treatment of homeowners and tenants. Specifically addressing tax liability variations within given income groups, the authors provided evidence that subsidy elimination would actually reduce this variation and tend to equalize tax liabilities within a given income group. Utilizing the same coefficient of variation measure, Pierce (1989) addressed both horizontal and vertical equity effects under several different policy alternatives. While the conclusions of both studies suggested that the tax provisions analyzed resulted in similarly situated taxpayers paying different amounts of tax, neither study addressed subsidy inequity effects related to geographical location.

Given the discussion above, this study explores the potential that horizontal equity is reduced as cost of housing differences across different regions interact with homeownership tax incentives to cause taxpayers in equal positions to pay different amounts of tax. Additionally, homeowner tax subsidies may also hinder vertical equity among taxpayers in that high income taxpayers are more likely to enjoy tax benefits from itemized deductions in excess of standard deduction allowances. Only to the extent of this excess is any benefit received from the actual deduction of mortgage interest and real property taxes. Adding to the problem, progressive tax rates provide high income taxpayers with greater tax savings for each $\$ 1$ of deductible expenditure than that provided to low income taxpayers. As a result, current homeowner tax incentives may inequitably encourage owner-occupied housing in geographical areas with a high cost of living and for individuals with higher incomes.

\section{DATA, ANALYTICAL MODEL, AND PROCEDURES}

As the latest available cross-sectional individual tax return data, the 1991 EY Model File was used to estimate homeowner tax subsidies enjoyed by individual taxpayers filing 1991 federal individual income tax returns. Providing a random sample of tax return information for U.S. taxpayers throughout the United States, District of Columbia, Puerto Rico, Guam and the Virgin Islands, the EY Model file consisted of an initial sample of 115,594 observations.

Adjustments deleting observations that reflected residence in the District of Columbia, Puerto Rico, Guam and the Virgin Islands reduced the sample by 6,677 to 108,917. Further, "high income" observation variable values in the EY sample have been modified by elimination or "blurring" to protect taxpayer confidentiality. ${ }^{1}$ Of key importance in this study, the elimination of state codes and other geographical indicators made state by state comparisons involving these high income observations impossible. After deletion of these observations, the final study sample consisted of 69,354 observations viewed as representative of non-high income US individual taxpayers. 


\section{VARIABLE IDENTIFICATION AND CONSTRUCTION}

Variables drawn from existing data sources were chosen to represent the following relevant taxpayer characteristics: state of residence (STATE), filing status (FILSTAT), household size (HHSIZE), and taxpayer disposable income (INCOME). For this purpose, STATE values reflected median housing costs acquired on a state by state basis from 1990 census data (Appendix A). Controlling for taxpayer family characteristics and responsibilities, FILSTAT and HHSIZE were available from the EY Model File. HHSIZE was calculated by reducing the taxpayer's total number of reported personal and dependency exemptions by the number of dependents claimed by, but not living with the taxpayer as a result of divorce or separation. FILSTAT values reflected whether the taxpayer filed as single, head of household, married filing jointly or married filing separate.

Representing a taxpayer's after-tax ability to consume, INCOME was constructed as AGI plus or minus adjustments for certain nontaxable receipts and nondeductible expenses recoverable from the individual's 1991 federal income tax return. Added to AGI were nontaxable receipts including certain portions of pension and IRA distributions, excluded social security benefits and tax-exempt interest. Subtracted from AGI were nondeductible expenses including federal tax liability before income tax credits, social security tax, medicare tax, recapture taxes, the alternative minimum tax, the tax on excess IRA distributions and nondeductible portions of self-employment taxes paid.

Finally, the homeowner tax subsidy was operationalized in two different manners to reflect tax savings received both at the federal level (FEDSUB) and at a level combining both federal and state effects (COBSUB). First, a tentative FEDSUB was calculated to reflect the benefit received from federal income tax deductions for mortgage interest and real property taxes. This tentative federal subsidy was calculated as the product of a taxpayer's 1) total federal itemized deductions for mortgage interest, property taxes and points and 2) the applicable federal marginal tax rate. Since tax savings attributable solely to the subsidy benefit a taxpayer only to the extent of any excess over savings that would otherwise be received from the standard deduction, FEDSUB was limited to the lower of the tentative subsidy or the product of the taxpayer's 1) applicable federal marginal tax rate and 2) total itemized deductions in excess of the allowable standard deduction.

For use in separate analysis, a combined subsidy (COBSUB) was also calculated in a similar manner. Accounting for tax savings received at both federal and state levels, COBSUB included the effects of state income tax homeowner incentives offered across thirty-two of the fifty United States. ${ }^{2}$ In calculating COBSUB, a review of the 1991 individual income tax law for each state was made. Information from the federal returns was then used to estimate the state of residence homeowner tax subsidy for each taxpayer in the sample. ${ }^{3}$ The result was added to the taxpayer's calculated federal subsidy in reaching a value for COBSUB.

\section{DESCRIPTIVE STATISTICS}

Table 1 details the average values by state for FEDSUB and COBSUB among sample taxpayers receiving a subsidy. Exhibiting strong distinctions, sample California subsidy recipients enjoyed an average combined subsidy (COBSUB) of $\$ 4,470$. Alternatively, sample South Dakota taxpayers benefited from average combined tax savings of only $\$ 841$. Exemplifying the divergence throughout this sample, results revealed that taxpayers in the seven states ranking highest in average subsidies received an average COBSUB of more than $\$ 3,500$. On the other hand, taxpayers in the seven states ranking lowest in average subsidies received an average COBSUB of less than $\$ 1,300$.

Further, a disparity in the percentage of total taxpayers receiving a combined subsidy across states is also evident. Over 52\% of Maryland taxpayers within this sample received a combined subsidy. Contrast this figure with the comparable value for South Dakota taxpayers of only $16 \%$. Together, these results provide evidence of potential horizontal inequities resulting from homeowner tax incentives. Vertical equity impacts are reflected in differences in tax liabilities among income groups. ${ }^{4}$ Table 2 illustrates average values for COBSUB by disposable income group for 1) only subsidy recipients (column 1 and 2) all taxpayers within the sample (column 2). Consistent with Table 1, the percentage of taxpayers receiving a combined subsidy within each income group is also presented (column 3). 
Table 1: Average Combined Subsidy By State

\begin{tabular}{|c|c|c|c|}
\hline STATE & FEDSUB & COBSUB & COBSUB RECIPIENTS \\
\hline California & $\$ 3,660$ & $\$ 4,470$ & $47.17 \%$ \\
\hline New Jersey & $\$ 3,008$ & $\$ 3,008$ & $49.67 \%$ \\
\hline Hawaii & $\$ 2,924$ & $\$ 4,048$ & $39.08 \%$ \\
\hline Connecticut & $\$ 2,897$ & $\$ 2,897$ & $48.37 \%$ \\
\hline New York & $\$ 2,860$ & $\$ 3,345$ & $44.50 \%$ \\
\hline Maryland & $\$ 2,833$ & $\$ 3,281$ & $52.95 \%$ \\
\hline New Hampshire** & $\$ 2,792$ & $\$ 2,792$ & $40.95 \%$ \\
\hline Massachusetts & $\$ 2,669$ & $\$ 2,669$ & $46.36 \%$ \\
\hline Virginia & $\$ 2,665$ & $\$ 3,160$ & $47.68 \%$ \\
\hline Nevada** & $\$ 2,427$ & $\$ 2,427$ & $38.78 \%$ \\
\hline Illinois & $\$ 2,346$ & $\$ 2,346$ & $39.24 \%$ \\
\hline Alaska** & $\$ 2,252$ & $\$ 2,252$ & $27.20 \%$ \\
\hline Florida** & $\$ 2,194$ & $\$ 2,194$ & $35.29 \%$ \\
\hline Georgia & $\$ 2,170$ & $\$ 2,762$ & $43.40 \%$ \\
\hline Washington** & $\$ 2,151$ & $\$ 2,151$ & $38.73 \%$ \\
\hline Pennsylvania & $\$ 2,116$ & $\$ 2,116$ & $37.52 \%$ \\
\hline Vermont & $\$ 2,050$ & $\$ 2,705$ & $44.13 \%$ \\
\hline Minnesota & $\$ 2,030$ & $\$ 3,236$ & $45.82 \%$ \\
\hline Rhode Island & $\$ 2,028$ & $\$ 2,586$ & $45.21 \%$ \\
\hline Texas** & $\$ 2,016$ & $\$ 2,016$ & $31.10 \%$ \\
\hline Arizona & $\$ 1,884$ & $\$ 2,217$ & $45.52 \%$ \\
\hline Michigan & $\$ 1,854$ & $\$ 1,854$ & $43.30 \%$ \\
\hline Maine & $\$ 1,803$ & $\$ 2,256$ & $32.57 \%$ \\
\hline Colorado & $\$ 1,786$ & $\$ 2,125$ & $46.79 \%$ \\
\hline Delaware & $\$ 1,727$ & $\$ 2,241$ & $48.98 \%$ \\
\hline North Carolina & $\$ 1,716$ & $\$ 2,179$ & $40.33 \%$ \\
\hline Oregon & $\$ 1,695$ & $\$ 2,196$ & $47.67 \%$ \\
\hline Ohio & $\$ 1,670$ & $\$ 1,670$ & $35.90 \%$ \\
\hline Wisconsin & $\$ 1,667$ & $\$ 1,952$ & $39.79 \%$ \\
\hline Tennessee $* *$ & $\$ 1,632$ & $\$ 1,632$ & $28.06 \%$ \\
\hline Louisiana & $\$ 1,613$ & $\$ 1,762$ & $29.02 \%$ \\
\hline South Carolina & $\$ 1,607$ & $\$ 1,964$ & $38.97 \%$ \\
\hline Kansas & $\$ 1,590$ & $\$ 1,845$ & $35.52 \%$ \\
\hline Idaho & $\$ 1,516$ & $\$ 1,848$ & $36.72 \%$ \\
\hline Alabama & $\$ 1,512$ & $\$ 1,772$ & $32.49 \%$ \\
\hline New Mexico & $\$ 1,499$ & $\$ 1,916$ & $32.33 \%$ \\
\hline Nebraska & $\$ 1,452$ & $\$ 1,699$ & $29.29 \%$ \\
\hline Indiana & $\$ 1,430$ & $\$ 1,430$ & $33.54 \%$ \\
\hline Missouri & $\$ 1,428$ & $\$ 1,650$ & $33.81 \%$ \\
\hline Utah & $\$ 1,418$ & $\$ 1,712$ & $48.76 \%$ \\
\hline Mississippi & $\$ 1,354$ & $\$ 1,606$ & $27.13 \%$ \\
\hline Wyoming** & $\$ 1,346$ & $\$ 1,346$ & $20.42 \%$ \\
\hline Montana & $\$ 1,295$ & $\$ 1,757$ & $28.28 \%$ \\
\hline West Virginia** & $\$ 1,282$ & $\$ 1,282$ & $24.14 \%$ \\
\hline Oklahoma & $\$ 1,228$ & $\$ 1,483$ & $36.15 \%$ \\
\hline Kentucky & $\$ 1,218$ & $\$ 1,516$ & $33.72 \%$ \\
\hline Iowa & $\$ 1,175$ & $\$ 1,527$ & $30.02 \%$ \\
\hline Arkansas & $\$ 1,027$ & $\$ 1,243$ & $29.56 \%$ \\
\hline North Dakota & $\$ 940$ & $\$ 1,298$ & $25.70 \%$ \\
\hline South Dakota" & $\$ 841$ & $\$ 841$ & $12.81 \%$ \\
\hline
\end{tabular}

** State with no income tax 
Table 2: Average Combined Subsidy By Disposable Income Group

\begin{tabular}{|c||c|c|c|c||}
\hline Disposable Income Group & $\begin{array}{c}\text { Average Subsidy Over } \\
\text { Recipients Only }\end{array}$ & $\begin{array}{c}\text { Average Subsidy Over } \\
\text { Total Sample }\end{array}$ & $\begin{array}{c}\text { \% Income Group } \\
\text { Receiving Subsidy }\end{array}$ & $\begin{array}{c}\text { \% Difference Between } \\
\text { Income Groups }\end{array}$ \\
\hline \hline$\$ 0-\$ 20,000$ & $\$ 411$ & $\$ 23$ & 0.0547 & N/A \\
\hline \hline$\$ 20,001-\$ 40,000$ & $\$ 921$ & $\$ 351$ & 0.3815 & 0.3268 \\
\hline \hline$\$ 40,001-\$ 60,000$ & $\$ 1,828$ & $\$ 1,249$ & 0.6833 & 0.3018 \\
\hline \hline$\$ 60,001-\$ 80,000$ & $\$ 3,144$ & $\$ 2,508$ & 0.7977 & 0.1144 \\
\hline \hline$\$ 80,001-\$ 120,000$ & $\$ 4,432$ & $\$ 3,731$ & 0.8419 & 0.0442 \\
\hline \hline Greater than $\$ 120,000$ & $\$ 5,704$ & $\$ 4,834$ & 0.8475 & 0.0056 \\
\hline
\end{tabular}

Examination of the results indicate potential vertical inequities. Note the $\$ 411$ average subsidy per recipient and the 5.47 percent of taxpayers receiving the subsidy for individuals with disposable incomes between $\$ 0$ and $\$ 20,000$. Increasing with disposable income, these values raise to $\$ 921$ and 38.15 percent, respectively, for sample taxpayers with disposable incomes between $\$ 20,000$ and $\$ 40,000$. Though exhibiting a diminishing rate of increase, this pattern continues for each income group throughout the sample. Further, this pattern was not "averaged out" when all taxpayers in the sample were included. As illustrated, the average subsidy increases over tenfold from $\$ 23$ to $\$ 351$ between the first and second income groups. As before, the pattern of increases for all taxpayers continues at a diminishing rate with increases in disposable income. Together, these descriptive statistics marked potential inequities in the system to be tested using the following analytical model.

\section{MODEL}

In an examination of potential relationships between homeowner tax subsidies and the variables detailed above, ordinary least squares regression techniques were used in estimating the following model:

SUBSIDY $=\beta_{0}+\beta_{1}$ STATE $+\beta_{2}$ INCOME $+\beta_{3}$ FILSTAT $+\beta_{4}$ HHSIZE,

where,

SUBSIDY $=$ homeowner tax subsidy (tax savings generated solely from the deduction of home mortgage interest and real property taxes); ${ }^{5}$

STATE $=\quad$ state of residence median housing cost;

INCOME $=\quad$ taxpayer disposable income;

FILSTAT $=\quad$ filing status indicator control variable; and

Based on a priori beliefs, SUBSIDY was expected to relate positively within the model to STATE, INCOME and HHSIZE. Consistent with Follain and Ling's (1991) conclusions, a positive relationship between SUBSIDY and INCOME would provide evidence compatible with vertical inequities. That is, utilization of subsidy benefits would provide higher income, marginal tax bracket individuals with relatively higher tax liability reductions.

Alternatively, horizontal inequities would be indicated by a significantly positive relationship between SUBSIDY and STATE. A priori, taxpayers in high median housing cost states, such as Maryland and Hawaii, were expected to receive higher subsidies than residents in low cost states, such as South Dakota. Additional evidence would be provided by a higher percentage of taxpayers receiving subsidy benefits in high cost states relative to low cost states.

Finally, a positive relationship between SUBSIDY and HHSIZE was expected for several reasons. First, a larger household in terms of the number of occupants was expected to be associated with the purchase of a larger home and accompanying larger interest and property tax costs. Second, increased liquidity constraints resulting from a higher number of dependents were expected to be related to increased proportions of financed housing costs. Table 3 
summarizes these a priori beliefs in formal hypotheses.

Table 3: Homeowner Tax Subsidy Hypotheses (stated in the null)

Ho1: Homeowner tax subsidy does not increase with increases in taxpayer disposable income.

Ho2: Homeowner tax subsidy does not increase with increases in taxpayer household size.

Ho3: Homeowner tax subsidy is not higher in states with higher costs of living.

\section{RESULTS}

Table 4 summarizes parameter estimates resulting from several applications of ordinary least squares techniques to the hypothesized model above. Applications are distinguished in that regressions I and II employed only the federal subsidy (FEDSUB) as a dependent variable. Regressions III and IV employed the combined federal and state subsidy (COBSUB). Within this framework, regressions I and III incorporated a sample of only subsidy recipients. The sample for regressions II and IV included all taxpayers (whether or not they benefited from homeowner tax subsidies).

Table 4: Regression Model Estimates

\begin{tabular}{|c|c|c|c|c|}
\hline \multirow{3}{*}{ Variable } & \multicolumn{2}{|c|}{ Fedsub Models } & \multicolumn{2}{|c|}{ "Cobsub Models } \\
\hline & Regression I & Regression II & Regression III & Regression IV \\
\hline & $\begin{array}{c}\text { Subsidy } \\
\text { Recipients } \\
\text { Only }\end{array}$ & $\begin{array}{l}\text { Total } \\
\text { Sample }\end{array}$ & $\begin{array}{c}\text { Subsidy } \\
\text { Recipients } \\
\text { Only }\end{array}$ & $\begin{array}{l}\text { Total } \\
\text { Sample }\end{array}$ \\
\hline \multirow{2}{*}{$\begin{array}{l}\text { Intercept } \\
p \text {-value }\end{array}$} & 130.97 & -433.22 & 5.684769 & -602.53 \\
\hline & $(.0701)$ & $* * *(.0001)$ & $(.9466)$ & $* * *(.0001)$ \\
\hline \multirow{2}{*}{$\begin{array}{l}\text { Filing Status (FILESTAT) } \\
p \text {-value }\end{array}$} & -13.93 & -77.559 & -24.159067 & -92.89 \\
\hline & $(.6484)$ & $* * *(.0001)$ & $(.5012)$ & $* * *(.0001)$ \\
\hline \multirow{2}{*}{$\begin{array}{l}\text { Household Size (HHSIZE) } \\
\text { p-value }\end{array}$} & 295.83 & 314.954 & 328.4412 & 369.24 \\
\hline & $* * *(.0001)$ & $* * *(.0001)$ & $* * *(.0001)$ & $* * *(.0001)$ \\
\hline \multirow{2}{*}{$\begin{array}{l}\text { Disposable Income (INCOME) } \\
p \text {-value }\end{array}$} & 0.000214 & 0.000483 & 0.00025 & 0.000551 \\
\hline & $* * *(.0001)$ & $* * *(.0001)$ & $* * *(.0001)$ & $* * *(.0001)$ \\
\hline \multirow{2}{*}{$\begin{array}{l}\text { State Variable (STATE) } \\
p \text {-value }\end{array}$} & 0.013444 & 0.007446 & 0.016922 & 0.009598 \\
\hline & $* * *(.0001)$ & $* * *(.0001)$ & $* * *(.0001)$ & $* * *(.0001)$ \\
\hline Model Adjusted R-Squared & 0.0814 & 0.0799 & 0.0872 & 0.0845 \\
\hline
\end{tabular}

***Significant for alpha value of .05

As indicated, all regression results were consistent with a priori beliefs and reflected statistically significant positive relationships between homeowner tax subsidy and (INCOME, HHSIZE and STATE. Again, consistent with Follain and Ling's (1991) conclusions, regressive effects of the subsidy were indicated in the relationship between the homeowner subsidy and INCOME $\left(\mathrm{Ho}_{1}\right.$ rejected). Horizontal inequity effects were further evidenced in this sample in the positive relationship between the homeowner subsidy and STATE $\left(\mathrm{HO}_{3}\right.$ rejected). While larger households statistically related to higher subsidies $\left(\mathrm{HO}_{2}\right.$ rejected), results for the relationship between homeowner subsidy and FILSTAT was mixed. Potentially reflecting the effect of community property versus common law states, the relationship between FILSTAT and homeowner subsidy was statistically significant in models applied to the total sample and insignificant in models applied to subsidy receivers only. 
Further comparison between FEDSUB and COB SUB models (comparing Regressions I to III and II to IV) exhibited larger coefficients for HHSIZE, INCOME and STATE in the COBSUB models, suggesting that state income tax homeowner incentives act to further exaggerate inequitable outcomes produced by federal homeowner tax incentives.

\section{CONCLUSIONS AND POLICY IMPLICATIONS}

In 1949, the United States Congress set as a national goal "a decent home and suitable living environment for every American family" (Weicher, 1979, p. 470). In describing increased efficiencies generated by positive externalities associated with higher homeownership rates, Rosen $(1988,144)$ stated:

Homeowners take good care of their property, keep it clean, etc., all of which make the other people in the neighborhoods better off, hence, the externality. In addition, homeownership provides an individual with a stake in the nation. This tends to increase social stability, another desirable spillover effect.

In presenting evidence of a strong relationship between homeowner tax incentives and increased owneroccupancy rates in the United States, prior research has attested to the success of these incentives as one method of reaching this objective. However, this examination suggests that this goal may have been reached at the expense of equity in the system.

Based on the results of this study, itemized deductions for mortgage interest and real property taxes appear to diminish horizontal equity in the individual income tax system as taxpayers possessing similar pre-tax consumption abilities pay different amounts of tax. Further, high income/marginal tax bracket taxpayers are provided with relatively larger subsidies than low income/marginal tax bracket taxpayers. Additionally, benefits appear to be distributed unequally across the fifty states with taxpayers in high cost of housing states receiving relatively higher benefits than similarly situated taxpayers in low cost of housing states. For individuals believing in the merits of a progressive system, homeowner tax subsidies appear to diminish vertical equity within the system as well.

These inequities are especially prevalent for low income taxpayers in low income states. While it can be argued that other federal and state government programs address these effects, total dollars spent on these programs pale in comparison to the amount of tax expenditures provided by mortgage interest and real property tax deductibility. Elimination of these tax expenditure provisions accompanied by direct subsidy distribution to homeowners might accomplish policy objectives while not hindering equity within the income tax system.

\section{ENDNOTES}

1. The term high income returns refers to observations in the initial data file which reflected total income or loss of $\$ 5,000,000$ or more; business plus farm receipts of $\$ 50,000,000$ or more; foreign earned income and total income of $\$ 2,000,000$ or more or total loss of $\$ 250,000$ or more; and nontaxable returns with adjusted gross incomes (AGI) or expanded incomes of $\$ 200,000$ or more.

2. For 1991, ten states imposed no income tax and eight states offered no form of state income tax subsidy for homeowners (Appendix B).

3. While the computation for itemized deductions was similar to that performed for the federal returns, several common distinctions exist. For example, one common difference involves the disallowance in most states of a deduction for state and local income taxes. As a result, refunds of state and local income taxes are generally not subject to state income tax. Adjustments such as these, as well as other necessary adjustments unique to a limited number of states, were made on a state by state basis to estimate the state tax savings (state homeowner subsidy) resulting from the deduction of mortgage interest and property taxes.

4. While prior equity studies have determined income groups on the basis of marginal tax rates, no clear theoretical justification existed concerning group threshold determinations in the current study. While using marginal tax rate bracket thresholds would incorporate the relationship between taxpayer subsidy and tax rate, the subsidy is also dependent on such taxpayer factors as the cost of a home, the percentage of a home which is debt financed, and the total dollar amount of other itemized deductions incurred by a taxpayer. 
5. Dependent upon the particular subsidy being examined (federal or combined federal and state), SUBSIDY was reflected by the utilization of either FED SUB or COBSUB.

\section{REFERENCES}

1. Follain, James R. and David C. Ling, The Federal Tax Subsidy to Housing and the Reduced Value of the Mortgage Interest Deduction, 44 The National Tax Journal, (1991), pp. 146-166.

2. Hendershott, Patrick H. and James R. Shilling, The Economics of Tenure Choice, 1955-1979, in Research in Real Estate, C. Sirmans ed., Jai Press, Greenwich, CT, (1982), pp. 105-133.

3. Gale Research, Inc., American Cost of Living Survey, $3^{\text {rd }}$ Ed., Farmington Hills, MI, (2002).

4. Mill, J.S., 1848 Principles of Political Economy, W. G. Ashley, ed., Longman's, 1921, Book 5, Chapter 2, p. 804.

5. Musgrove, Richard A., Horizontal Equity, Once More, 43 National Tax Journal, (1990), pp. 113-122.

6. Pierce, Bethane J., Homeowner Preferences: The Equity and Revenue Effects of Proposed Changes in the Status Quo, 10 The Journal of the American Taxation Association, (Spring, 1989), pp. 54-67.

7. President's Advisory Panel on Federal Tax Reform., Simple, Fair, and Pro-Growth: Proposals to Fix America's Tax System. Washington, D.C.: U.S. Government Printing Office, 2005.

8. $\quad$ Rosen, Harvey S., Public Finance, Irwin, Homewood, IL, 1988.

9. Rosen, Harvey S., Housing Decisions and the U.S. Income Tax, 11 Journal of Public Economics (1979), pp. $1-23$.

10. Rosen, Harvey S. and Kenneth T. Rosen, Federal Taxes and Homeownership: Evidence from Time Series, 88 Journal of Political Economy (1980), pp. 59-75.

11. Weicher, John, C., Housing: Federal Policies and Programs American Enterprise Institute, Washington, D.C., (1980).

12. White, Melvin and Anne White, Horizontal Inequality in the Federal Income Tax Treatment of Homeowners and Tenants, 18 National Tax Journal. (September, 1965), pp. 225-239.

\section{APPENDIX A}

1990 Median Housing Values By State

\begin{tabular}{|c|c|}
\hline Hawaii & $\$ 245,300$ \\
\hline California & $\$ 195,500$ \\
\hline Connecticut & $\$ 177,800$ \\
\hline Massachusetts & $\$ 162,800$ \\
\hline New Jersey & $\$ 162,300$ \\
\hline Rhode Island & $\$ 133,500$ \\
\hline New York & $\$ 131,600$ \\
\hline New Hampshire & $\$ 129,400$ \\
\hline Maryland & $\$ 116,500$ \\
\hline Delaware & $\$ 100,100$ \\
\hline Nevada & $\$ 95,700$ \\
\hline Vermont & $\$ 95,500$ \\
\hline Alaska & $\$ 94,400$ \\
\hline Washington & $\$ 93,400$ \\
\hline Virginia & $\$ 92,000$ \\
\hline Maine & $\$ 87,400$ \\
\hline Colorado & $\$ 82,700$ \\
\hline Illinois & $\$ 80,900$ \\
\hline Arizona & $\$ 80,100$ \\
\hline Florida & $\$ 77,100$ \\
\hline Minnesota & $\$ 74,000$ \\
\hline Georgia & $\$ 71,300$ \\
\hline New Mexico & $\$ 70,100$ \\
\hline Pennsylvania & $\$ 69,700$ \\
\hline
\end{tabular}




\begin{tabular}{||c|c||}
\hline Utah & $\$ 68,900$ \\
\hline Oregon & $\$ 67,100$ \\
\hline North Carolina & $\$ 65,800$ \\
\hline Ohio & $\$ 63,500$ \\
\hline Wisconsin & $\$ 62,500$ \\
\hline Wyoming & $\$ 61,600$ \\
\hline South Carolina & $\$ 62,100$ \\
\hline Michigan & $\$ 60,600$ \\
\hline Missouri & $\$ 59,800$ \\
\hline Texas & $\$ 59,600$ \\
\hline Louisiana & $\$ 58,500$ \\
\hline Tennessee & $\$ 58,400$ \\
\hline Idaho & $\$ 58,200$ \\
\hline Montana & $\$ 56,600$ \\
\hline Indiana & $\$ 53,900$ \\
\hline Alabama & $\$ 53,700$ \\
\hline Kansas & $\$ 52,200$ \\
\hline North Dakota & $\$ 50,800$ \\
\hline Kentucky & $\$ 50,500$ \\
\hline Nebraska & $\$ 50,400$ \\
\hline Oklahoma & $\$ 48,100$ \\
\hline West Virginia & $\$ 47,900$ \\
\hline Arkansas & $\$ 46,300$ \\
\hline Iowa & $\$ 45,900$ \\
\hline Mississippi & $\$ 45,600$ \\
\hline South Dakota & $\$ 45,200$ \\
\hline & \\
\hline
\end{tabular}

APPENDIX B

States Receiving Federal and/or State Homeowner's Subsidy

\begin{tabular}{||c|c|c|c||}
\hline \hline Alabama & Idaho & Mississippi & Oklahoma \\
\hline Arizona & Iowa & Missouri & Oregon \\
\hline Arkansas & Kansas & Montana & Rhode Island \\
\hline California & Kentucky & Nebraska & South Carolina \\
\hline Colorado & Louisiana & New Mexico & Utah \\
\hline Delaware & Maine & New York & Vermont \\
\hline Georgia & Maryland & North Carolina & Virginia \\
Hawaii & Minnesota & North Dakota & Wisconsin \\
\hline
\end{tabular}

States With No Income Tax

\begin{tabular}{||c|c||}
\hline Alaska & Tennessee \\
\hline Florida & Texas \\
\hline Nevada & Washington \\
\hline New Hampshire & West Virginia \\
\hline South Dakota & Wyoming \\
\hline
\end{tabular}

States Offering No Homeowner Interest/Property Tax Deductions

\begin{tabular}{||c|c||}
\hline Connecticut & Michigan* \\
\hline Illinois* & New Jersey* \\
\hline Indiana & Ohio \\
\hline Massachusetts & Pennsylvania \\
\hline
\end{tabular}

* incapable of computing benefit from property 